\title{
CTLA4 CT60 gene polymorphism is not associated with differential susceptibility to pemphigus foliaceus
}

\author{
Márcia Regina Pincerati, Ricardo Dalla-Costa and Maria Luiza Petzl-Erler \\ Laboratório de Genética Molecular Humana, Departamento de Genética, \\ Universidade Federal do Paraná, Curitiba, PR, Brazil.
}

\begin{abstract}
Pemphigus foliaceus is an organ-specific autoimmune disease characterized by autoantibodies against the extracellular region of desmoglein 1, a protein that mediates intercellular adhesion in desmosomes. Cytotoxic Tlymphocyte-associated protein 4 (CTLA-4) is a key negative regulator of the T cell immune response, playing an important role in T cell homeostasis and maintenance of peripheral tolerance. Polymorphisms in the CTLA4 gene have been associated with autoimmune diseases and the functional CT60 single nucleotide polymorphism (rs3087243, also named $6230 \mathrm{G}>A$ ) has been proposed to be a casual variant in several of these diseases. The aim of this study was to ascertain whether this polymorphism is associated with inter-individual variation in susceptibility to pemphigus foliaceus. The population sample in this case-control association study comprised 248 patient and 367 controls. We did not found a significant association of pemphigus foliaceus with the CT60 variants. We conclude that the CTLA4 CT60 polymorphism is not an important factor for pemphigus foliaceus pathogenesis in the population analyzed.
\end{abstract}

Key words: CTLA4, CT60 polymorphism, pemphigus, fogo selvagem, autoimmunity.

Received: December 4, 2009; Accepted: February 3, 2010.

The $2 \mathrm{q} 33$ chromosome region harbors genes that encode costimulatory molecules, such as the cytotoxic T-lymphocyte-associated protein 4 (CTLA4), the cluster of differentiation molecule 28 (CD28) and the inducible costimulatory molecule (ICOS), all of which play crucial roles in $\mathrm{T}$ cell activation and regulation (Ling et al., 2001).

CTLA-4 is a key molecule expressed by activated $\mathrm{T}$ cells that transduces an inhibitory signal after binding to CD80 or CD86 on antigen-presenting cells. CTLA-4 appears to inhibit immune responses by several mechanisms, besides being a critical mediator in peripheral tolerance. Based on its crucial role in immunological homeostasis, CTLA4 has become one of the main genes of research interest for association studies and has been considered as a target for immunotherapy (Scalapino and Daikh, 2008). Polymorphisms in CTLA4 are associated with a very wide range of inflammatory and autoimmune diseases (for a review, see Kristiansen et al., 2000; Gough et al., 2005). Several SNPs have been identified in the $2 \mathrm{q} 33$ region comprising CD28, CTLA4 and ICOS genes (Ueda et al., 2003). The authors found associations between polymorphisms in the segment that includes the 3 ' region of the CTLA4 gene with

Send correspondence to Maria Luiza Petzl-Erler. Laboratório de Genética Molecular Humana, Departamento de Genética, Universidade Federal do Paraná, Caixa Postal 19071, 81531-980 Curitiba, PR, Brazil. E-mail: perler@ufpr.br.
Graves disease, hypothyroidism and autoimmune type I diabetes. Among these polymorphisms, the SNP $C T 60 G>A$ (rs3087243, also denominated $6230 G>A$ ), was the mostassociated marker. The $C T 60^{*} G$ allele was correlated with higher disease susceptibility and lower mRNA levels of the soluble alternative splice form of CTLA-4 (sCTLA-4). Recent studies also suggested that polymorphisms in the CTLA4 gene may influence the development of autoimmune diseases. Palacios et al. (2008) concluded that regulatory SNPs in the CTLA4 gene exert a strong influence on expression levels of both known CTLA-4 isoforms. Moreover, association between CT60 polymorphism and variation in the frequency of regulatory $\mathrm{T}$ cells has been reported. Individuals homozygous for allele $C T 60^{*} A$ showed an increase from $30-40 \%$ in the frequency of regulatory $\mathrm{T}$ cells. Although the basic mechanism connecting the $C T 60^{*} A$ allele with an increase in regulatory $\mathrm{T}$ cells has not yet been established, these differences reveal a relationship between CT60 polymorphism and variation in adaptive immune responses (Atabani et al., 2005).

Endemic pemphigus foliaceus (PF), also known as fogo selvagem (meaning 'wild fire'), is an organ-specific autoimmune disease characterized by autoantibodies against desmoglein 1 protein and by loss of adhesion between keratinocytes, leading to intraepithelial blisters of the skin (Warren et al., 2000). Several candidate genes have been analyzed for associations with PF. The HLA class II 
genes (Pavoni et al., 2003) and the CD40L gene (Malheiros and Petzl-Erler, 2009) showed the strongest associations. In addition, interactions between some of the genes analyzed have been reported (Martel et al., 2002; Malheiros and Petzl-Erler, 2009). Two SNPs in the CTLA4 gene, $-318 C>T$ and $49 A>G$, had been previously analyzed, although no association with PF disease susceptibility was observed (Pavoni et al., 2006).

Based on the reported associations between susceptibility to autoimmune diseases and CTLA4 polymorphisms, especially the CT60 SNP, the aim of this study was to extend analysis of this candidate gene to evaluate whether the CT60 polymorphism is a factor contributing to differential genetic susceptibility to pemphigus foliaceus in the Brazilian population.

We analyzed 248 patients and 367 controls without history of the disease, all unrelated to each other. Diagnosis was according to clinical and histological criteria. Patients and controls were contacted at Hospital Adventista do Pênfigo, Campo Grande, Mato Grosso do Sul State, Brazil. Additional controls were contacted in Curitiba, Paraná State, Brazil. Patients and controls were matched for ancestry. Seventy percent of the individuals were of predominantly European and $30 \%$ of predominantly African ancestry. The male:female ratio was close to one, viz. $47 \%$ of the patients and $45 \%$ of the controls were males. According to age of disease onset, distribution was as follows: from 0 to 9 years, $4.2 \%$; $10-14$ years, $8.3 \%$; 15-19, 13.1\%; 20-24, 11.3\%; $25-29,9.5 \% ; 30-34,9.5 \% ; 35-39,12.9 \% ; 40-44,8.3 \%$; $45-49,10.1 \%$; 50-59, 5.4\%; 60-69, 4.2\%; 70-84, 3.6\%. Written informed consent was obtained from all the participants. The study received approval by the Human Research Ethics Committee, in accordance with Brazilian Federal Laws.

Genotyping was performed by polymerase chain reaction amplification followed by restriction fragment length polymorphism analysis (PCR-RFLP). The primers and PCR conditions were the same as those described by Teutsch et al. (2004). Allelic, genotypic and allele carrier frequencies (i.e., the frequency of individuals having the allele in either homozygosity or heterozygosity) were estimated by direct counting. Hardy-Weinberg equilibrium was assessed with the Guo and Thompson (1992) method implemented in the ARLEQUIN version 3.11 software package (Excoffier et al., 2005). Comparisons between frequencies in the patient and control population samples were performed by analysis of contingency tables by the chisquare test of independence. The strength of the associations was estimated by the odds ratio (OR), using Woolf's method. The $\mathrm{p}$ value of 0.05 was adopted as the significance limit for all statistical tests. The genotype taken as reference was CTLA4 CT60 G/G. Therefore, by definition, the OR for this genotype equals 1 and the OR for $A / G$ and $A / A$ approach the risk of these genotypes relative to the $G / G$ genotype.
Allelic, genotypic and allele carrier frequencies are presented in Table 1. Genotype frequencies were in Hardy-Weinberg equilibrium $(\mathrm{p}=0.115$ and $\mathrm{p}=0.829$ in $\mathrm{pa}-$ tient and control population samples, respectively). No significant association between PF disease status and CT60 variants was detected.

Associations previously described between susceptibility to some autoimmune diseases and CT60 polymorphism have been interpreted considering the possible effect of this SNP in the alteration of the ratio of CTLA-4 splicing isoforms, and that elevated levels of SCTLA-4 have already been detected in certain autoimmune disorders (Ueda et al., 2003; Saverino et al., 2007; Kawasaki et al., 2008). In addition, the hypothesis has been raised that SCTLA-4 is involved in control of $\mathrm{T}$ cell activation, its levels being regulated by genetic variation in chromosome region 2 q33 (Kaartinen et al., 2007). Although several diseases have been associated with CT60 polymorphism (see above), further studies of the same and other autoimmune diseases in various populations have failed to detect associations, thus concurring with our results (for example, Chang et al., 2007; Tsukahara et al., 2008). One reason for these conflicting results may be differences in allelic and haplotypic frequencies of this marker among populations. Another explanation is that the set of genes contributing to the establishment of different autoimmune diseases is not the same, and that the CTLA4 gene is important in some diseases but not in others.

In this study, we expanded our previous findings regarding variation in the CTLA4 gene by analyzing CT60 polymorphism. Our results lead to the conclusion that genetic variation in CTLA4 does not play an important role in PF susceptibility and that the effect of variations in this gene differs among autoimmune diseases. We do not exclude the involvement of the CTLA-4 molecule in PF

Table 1 - Genotypic, allele carrier, and allelic frequencies for the CT60 SNP in patients and controls.

\begin{tabular}{lccccc}
\hline & \multicolumn{2}{c}{ Frequency (\%) } & & & \\
\cline { 2 - 3 } & $\begin{array}{c}\text { Patients } \\
(\mathrm{n}=248)\end{array}$ & $\begin{array}{c}\text { Controls } \\
(\mathrm{n}=367)\end{array}$ & $\mathrm{OR}^{1}$ & $95 \% \mathrm{CI}^{2}$ & $\mathrm{p}^{3}$ \\
\hline Genotypes & & & & & \\
$G / G$ & 37.9 & 33.2 & 1 & & \\
$A / G$ & 43.1 & 49.6 & 0.76 & $0.53-1.09$ & 0.14 \\
$A / A$ & 19.0 & 17.2 & 1.03 & $0.65-1.64$ & 0.89 \\
Allele carriers & & & & & \\
$G+$ & 81.0 & 82.8 & 0.89 & $0.58-1.35$ & 0.57 \\
$A+$ & 62.1 & 66.8 & 0.82 & $0.58-1.14$ & 0.23 \\
Alleles & & & & & 0.62 \\
$G$ & 59.5 & 58.0 & 1.06 & $0.84-1.34$ & 0.62 \\
$A$ & 40.5 & 42.0 & 0.94 & $0.75-1.19$ & 0.62 \\
\hline
\end{tabular}

${ }^{1}$ Odds ratio $;{ }^{2}$ Confidence interval; ${ }^{3}$ Probability values. 
pathogenesis, but show that CT60 genotypes have no significant impact on pemphigus foliaceus disease susceptibility.

\section{Acknowledgments}

We thank the patient and control individuals for their collaboration. The support and friendship of our laboratory colleagues are highly valued. This work was supported by the Conselho Nacional de Desenvolvimento Científico e Tecnológico (CNPq), Fundação Araucária de Apoio ao Desenvolvimento Científico e Tecnológico do Paraná and Coordenação de Aperfeiçoamento de Pessoal de Nível Superior (CAPES).

\section{References}

Atabani SF, Thio CL, Divanovic S, Trompette A, Belkaid Y, Thomas DL and Karp CL (2005) Association of CTLA4 polymorphism with regulatory $\mathrm{T}$ cell frequency. Eur J Immunol 35:2157-2162.

Chang MC, Chang YT, Tien YW, Liang PC, Jan IS, Wei SC and Wong JM (2007) T-cell regulatory gene CTLA-4 polymorphism/haplotype association with autoimmune pancreatitis. Clin Chem 53:1700-1705.

Excoffier L, Laval G and Schneider S (2005) Arlequin v. 3.0. An integrated software package for populations genetics data analysis. Evol Bioinform Online 1:47-50.

Gough SC, Walker LS and Sansom DM (2005) CTLA4 gene polymorphism and autoimmunity. Immunol Rev 204:102115.

Guo SW and Thompson EA (1992) Performing the exact test of Hardy-Weinberg proportion for multiple alleles. Biometrics 48:361-372.

Kaartinen T, Lappalainen J, Haimila K, Autero M and Partanen J (2007) Genetic variation in ICOS regulates mRNA levels of ICOS and splicing isoforms of CTLA4. Mol Immunol 44:1644-1651.

Kawasaki E, Imagawa A, Makino H, Uga M, Abiru N, Hanafusa T, Uchigata Y and Eguchi K (2008) Differences in the contribution of the CTLA4 gene to susceptibility to fulminant and type 1A diabetes in Japanese patients. Diabetes Care 31:1608-1610.

Kristiansen OP, Larsen ZM and Pociot F (2000) CTLA-4 in autoimmune diaseses - A general susceptibility gene to autoimmunity? Genes Immun 1:170-184.

Ling V, Wu PW, Finnerty HF, Agostino MJ, Graham JR, Chen S, Jussiff JM, Fisk GJ, Miller CP and Collins M (2001) Assembly and annotation of human chromosome $2 \mathrm{q} 33$ sequence containing the CD28, CTLA4, and ICOS gene cluster: Analysis by computational, comparative, and microarray approaches. Genomics 78:155-168.
Malheiros D and Petzl-Erler ML (2009) Individual and epistatic effects of genetic polymorphisms of B cell co-stimulatory molecules on susceptibility to pemphigus foliaceus. Genes Immun 10:547-558.

Martel P, Gilbert D, Busson M, Loiseau P, Lepage V, Drouot L, Delaporte E, Prost C, Joly P, Charron D et al. (2002) Epistasis between DSG1 and HLA class II genes in pemphigus foliaceus. Genes Immun 3:205-210.

Palacios R, Comas D, Elorza J and Villoslada P (2008) Genomic regulation of CTLA4 and multiple sclerosis. J Neuroimmunol 203:108-115.

Pavoni DP, Roxo VM, Marquart FA and Petzl-Erler ML (2003) Dissecting the associations of endemic pemphigus foliaceus (fogo selvagem) with HLA-DRB1 alleles and genotypes. Genes Immun 4:110-116.

Pavoni DP, Cerqueira LB, Roxo VM and Petzl-Erler ML (2006) Polymorphism of the promoter region and exon 1 of the CTLA4 gene in endemic pemphigus foliaceus (fogo selvagem). Braz J Med Biol Res 39:1227-1232.

Saverino D, Brizzolara R, Simone R, Chiappori A, Milintenda-Floriani F, Pesce G and Bagnasco M (2007) Soluble CTLA-4 in autoimmune thyroid diseases: Relationship with clinical status and possible role in the immune response dysregulation. Clin Immunol 123:190-198.

Scalapino KJ and Daikh DI (2008) CTLA-4: A key regulatory point in the control of autoimmune disease. Immunol Rev 223:143-155.

Ueda H, Howson JM, Esposito L, Heward J, Snook H, Chamberlain G, Rainbow DB, Hunter KM, Smith AN, Di Genova G et al. (2003) Association of the T-cell regulatory gene CTLA4 with susceptibility to autoimmune disease. Nature 423:506-511.

Teutsch SM, Booth DR, Bennetts BH, Heard RN and Stewart GJ (2004) Association of common T cell activation gene polymorphisms with multiple sclerosis in Australian patients. J Neuroimmunol 148:218-230.

Tsukahara S, Iwamoto T, Ikari K, Inoue E, Tomatsu T, Hara M, Yamanaka H, Kamatani N and Momohara S (2008) CTLA-4 CT60 polymorphism is not an independent genetic risk marker of rheumatoid arthritis in a Japanese population. Ann Rheum Dis 67:428-429.

Warren SJ, Lin MS, Giudice GJ, Hoffmann RG, Hans-Filho G, Aoki V, Rivitti EA, Santos V and Diaz LA (2000) The prevalence of antibodies against desmoglein 1 in endemic pemphigus foliaceus in Brazil. Cooperative Group on Fogo Selvagem Research. N Engl J Med 343:23-30.

Associate Editor: Francisco Mauro Salzano

License information: This is an open-access article distributed under the terms of the Creative Commons Attribution License, which permits unrestricted use, distribution, and reproduction in any medium, provided the original work is properly cited. 